\title{
TENTOONSTELLING
}

\section{DE VERBORGEN VOET VAN DE BOROBUDUR}

De Borobudur op Java is dé toeristische trekpleister van Indonesië. Dit boeddhistische monument uit de $8^{\mathrm{e}}$ eeuw heeft een plek verworven op de werelderfgoedlijst van Unesco. De Borobudur heeft de vorm van een stupa; het meest karakteristieke boeddhistische bouwwerk ter ere van de Boeddha. Het bestaat uit vierkante en ronde terrassen met bovenop een klokvormige constructie. De terrassen staan symbool voor de drie niveaus in het kosmologisch systeem van boeddhisten: de wereld van het verlangen, de wereld van de vorm zonder verlangen en de wereld zonder vorm en zonder verlangen. Tegelijkertijd geven deze lagen de drie stappen van geestelijke groei naar verlossing weer. In de galerijtentoonstelling 'De verborgen voet van de Borobudur' besteedt Museum Volkenkunde voor het eerst aandacht aan een raadselachtig onderdeel van dit monument: de onderste bouwlaag waarvan de reliëfs grotendeels zijn afgedekt.

In 1885 ontdekten archeologen dat er achter de buitenste muur van het onderste terras nog een bouwlaag zat met 160 stenen reliëfs waarvan er 157 afgeschermd waren en maar drie zichtbaar. De complete 'verborgen voet' werd in 1890-1891 blootgelegd, gefotografeerd en weer bedekt. Waarom de reliëfs ooit zijn afgedekt is nog steeds een raadsel. Er zijn verschillende theorieën in omloop, die variëren van bouwkundig (door de dekplaten werd de stupa van een steviger basis te voorzien) tot iconografisch (de aanblik en betekenis van de afbeeldingen zou niet voor iedereen zichtbaar mogen zijn). De foto's uit de jaren '90 van de $19^{\mathrm{c}}$ eeuw, gemaakt door Kassian Céphas, zijn de basis van deze galerijtentoonstelling. Ze zijn in 1903 door het Rijksmuseum van Oudheden aan Museum Volkenkunde overgedragen. In de tentoonstelling zijn de foto's van 36 panelen uitgekozen die uitgebreid worden beschreven.

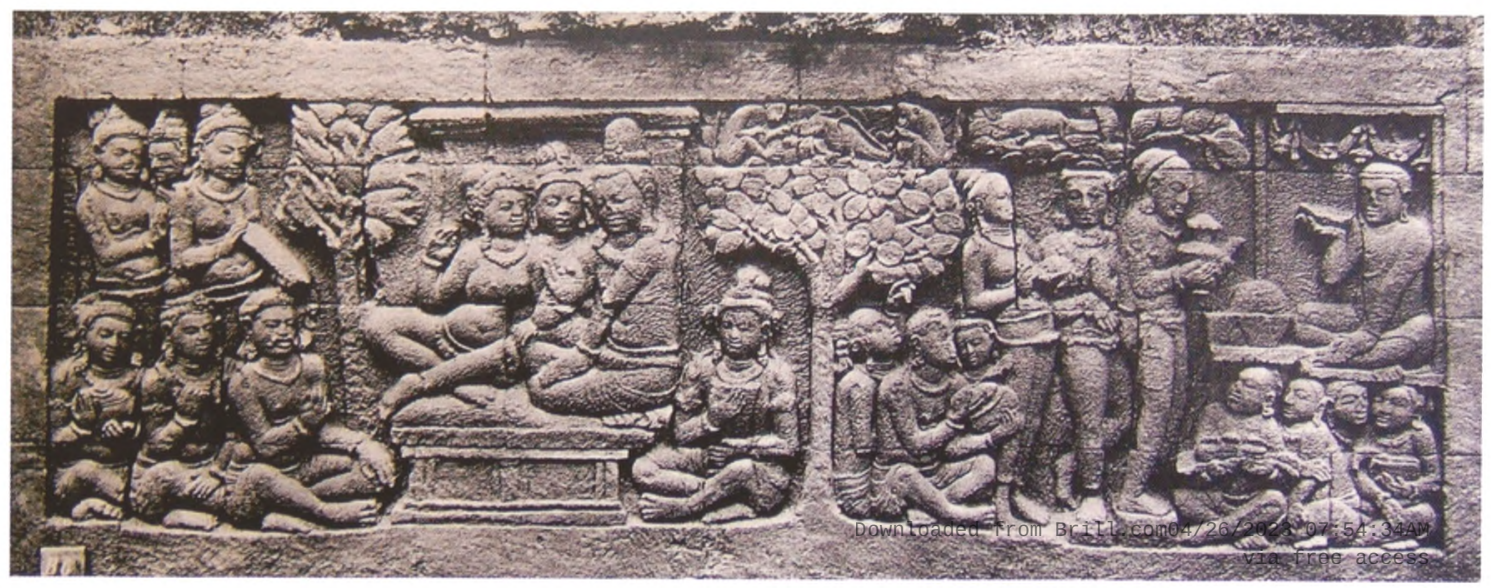


Op de website $w w w . v o l k e n k u n d e . n l$ kunnen via de database (zoekspecificatie 1403-3788-*) ook alle overige foto's worden bekeken.

Het hoofdthema op de reliëfs is beloning en vergelding. Behalve afbeeldingen van hemel en hel zijn scènes uit het dagelijkse leven te zien, wereldse successen en drama's; goede en slechte zaken die weer samenhangen met daden uit het verleden en die bepalen of een mens in de toekomst beloning of vergelding te wachten staat. Tegelijkertijd geven de reliëfs een beeld van het dagelijkse leven op Java aan het eind van de $8^{e}$ en de $9^{c}$ eeuw. Zo is er bijvoorbeeld een scène waarin uiterst rechts monniken zijn afgebeeld die eten en drinken ontvangen (de goede daad); links op hetzelfde reliëf is te zien hoe de weldoeners overvloedig leven, gezegend met liefde, schoonheid en hoge status ten deel valt: de beloning (afb. 1).

- 'De verborgen voet van de Borobudur' Van 16 februari $t / m 28$ september 2008 Museum Volkenkunde

Steenstraat 1 , Leiden www.volkenkunde.nl 